a

PEN ACCESS

EDITORS

- Miguel Oliveira, Jr. (UFAL)

- René Almeida (UFS)

REVIEWERS

- Lauren Gawne (La Trobe)

- Célia Schneebeli (UB)

DATES

-Received: 07/06/2021

-Accepted: 10/15/2021

-Published: 11/11/2021

HOW TO CITE

STEVERS, Alicia (2021). Emoji-Based Reactions to the Said Construction in Spanish and English. Cadernos de Linguística, v. 2, n. 3, e391.
RESEARCH REPORT

\section{EMOJI-BASED REACTIONS TO THE SAID CONSTRUCTION IN SPANISH AND ENGLISH}

\author{
Alicia STEVERS (D) $\boldsymbol{\Delta}$ \\ San Diego State University (SDSU)
}

\section{ABSTRACT}

The said construction (SC), a relatively common but understudied standard English construction, is usually characterized by the use of said in place of a determiner, followed by a noun (N2), typically given (in some sense) and licensed by an antecedent noun (N1). (e.g. "I made coffee... said coffee was bitter.") I present the results of a social media based experiment, focusing on the way participants react to SCcontaining sentences using the "reactions" buttons provided on many social media sites. Participants were presented with stimuli that looked like a Facebook profile; each item in the experiment had a "profile photo", a sentence that contained either a standard determiner like the or that, or SC, as well as an emoji-based reactions schema with the reaction options provided on Facebook. Participants were told to read each sentence and react to it using the provided emoji buttons. Results showed that SC-containing sentences were more likely to receive the " $\Theta /$ haha" reaction, whereas sentences containing a standard determiner received the " $/$ /like" reaction. These findings, in addition to open ended survey data collected from participants, suggest that SC may carry a humorous meaning that is not necessarily conveyed by a standard determiner. An identical experiment conducted with native Spanish speakers on the similar use of dicho show that this reaction tendency does not hold cross-linguistically. 
RESUMEN

Said construction (SC) es una construcción en inglés estándar relativamente común pero poco estudiada, generalmente se caracteriza por el uso de dicha construcción en lugar de un determinante, seguido de un sustantivo (N2), generalmente dado (en cierto sentido) y con licencia de un antecedente. sustantivo (N1) (por exemplo, "Fiz café... disse que o café estava amargo.") Presento los resultados de un experimento basado en redes sociales, centrándome en la forma en que los participantes reaccionan a las oraciones que contienen SC utilizando los botones de "reacciones" que se encuentran en muchos sitios de redes sociales. A los participantes se les presentaron estímulos que parecían un perfil de Facebook; cada elemento del experimento tenía una "foto de perfil", una oración que contenía un determinante estándar como el o ese, o SC, así como un esquema de reacciones basado en emoji con las opciones de reacción proporcionadas en Facebook. Se les pidió a los participantes que leyeran cada oración y reaccionaran a ella usando los botones emoji proporcionados. Los resultados mostraron que las oraciones que contenían SC tenían más probabilidades de recibir la reacción " $\theta$ / jaja", mientras que las oraciones que contenían un determinante estándar recibieron la reacción " $/$ / me gusta". Estos hallazgos, además de los datos de encuestas abiertas recopilados de los participantes, sugieren que SC puede tener un significado humorístico que no es necesariamente transmitido por un determinante estándar. Un experimento idéntico realizado con hispanohablantes nativos sobre el uso similar de dicho o dicha muestra que esta tendencia de reacción no se mantiene de manera interlingüística.

\section{KEYWORDS}

Experimental Pragmatics; Determiners; Emoji; Internet Language; Social Meaning.

\section{PALABRAS CLAVES}

Pragmática Experimental; Determinantes; Emoji; Idioma de Internet; Significado Social. 


\section{INTRODUCTION}

This study on the Said Construction (SC) is rooted in the sociolinguistic concept of social meaning, defined as "social content tied in the minds of a given speaker/hearer to a particular piece of linguistic behavior (CAMPBELL-KIBLER 2009). Determiners, generally considered a small, closed word class, do not seem to be a lexical category ripe for social meaning potential. We see from recent research, however, that there is meaning that can be conveyed through determiner choice. For example, choosing to use the with a groupdenoting noun (such as "the Republicans") can indicate non-membership to that group (ACTON 2014). The present work builds upon this finding, showing that said used as a determiner can potentially convey a humorous meaning. Although traditionally considered an adjective in dictionaries and grammar guides, the motivation for thinking of SC as a determiner construction is based on a corpus-based study showing that saidinteracts with information much like a determiner does; it is sensitive to notions of information status and has a referential quality that other adjectives lack (STEVERS 2020)'. For instance, said must be used with an entity that is already mentioned in the discourse, either explicitly or through a subtype/type relationship; it may not be used in inferential constructions. Examples 1a and $1 \mathrm{~b}$ below demonstrate the two most common informational environments in which SC can be found, as well as an ungrammatical example where it is used with inferrable information (STEVERS 2020)2.

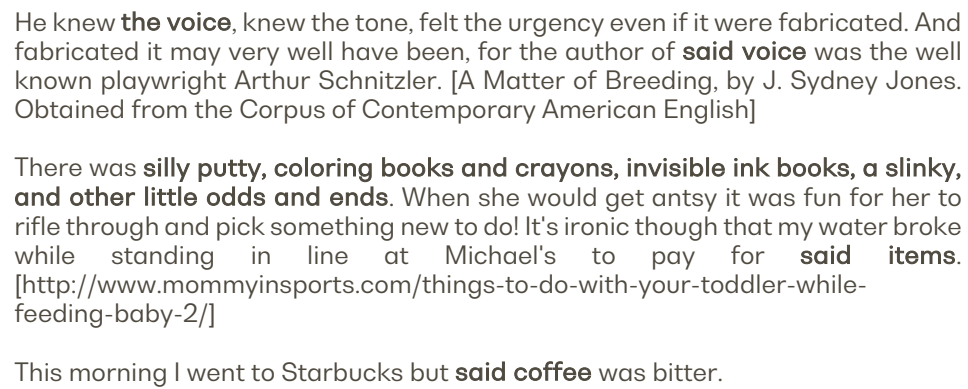
fabricated it may very well have been, for the author of said voice was the well known playwright Arthur Schnitzler. [A Matter of Breeding, by J. Sydney Jones. Obtained from the Corpus of Contemporary American English]

There was silly putty, coloring books and crayons, invisible ink books, a slinky, and other little odds and ends. When she would get antsy it was fun for her to rifle through and pick something new to do! It's ironic though that my water broke while standing in line at Michael's to pay for said items. [http://www.mommyinsports.com/things-to-do-with-your-toddler-whilefeeding-baby-2/]

This morning I went to Starbucks but said coffee was bitter.

Antecedent mentioned explicitly:

Antecedent forms

subtype/type relationship

Ungrammatical; no antecedent, and used inferentially

1c.
$1 a$.

A similar construction is also present in Spanish, which uses dicho/a similarly to said in English. The present studies seek to develop an understanding of how native speakers of

1 This small experiment is situated within a larger, multi-part dissertation study on SC which provides an overview of the history of the construction, how it has changed over time in syntactic form an usage, and how a similar Spanish construction using dicho has followed a different trajectory in terms of diachronic change and modern usage. The present paper focuses only on a social meaning experiment conducted on English speakers.

2 This is based on an in-depth corpus study of SC, which can be found in the dissertation from which the rest of this paper is based. 
these languages interpret the usage pragmatics of these constructions. We see from the results below that English and Spanish speakers react differently to sentences containing these constructions, providing evidence that while sharing the same Latin origin, the constructions are now interpreted differently by English and Spanish speakers.

Acton (2014) establishes a framework within which to investigate the social meaning of determiners. This framework consists of four main principles, the fourth of which I focus on here. This principle, the Violations of Expectations Principle (VE) is rooted in Grice's maxim of manner, and suggests that an utterance is likely to be given special attention within a discourse if it violates conversational expectations. A speaker who chooses a response that is unexpected should have a reason for doing so, and should be paid attention to. In turn, hearers are more likely to flag these types of utterances as significant, as one can assume that a speaker would have chosen an alternative, more expected utterance in the absence of significance. This principle closely relates to SC, which seems to violate conversational expectations. The use of a standard determiner form is of course not unusual, but the use of said is less common. It follows that a speaker would choose to use this form when they wish to draw attention or add emphasis or feeling to a particular point or referent in the discourse. I hypothesize that this emphasis is interpreted as a humorous one due to the unexpectedness of seeing a formal construction like SC in such informal discourse such as social media. Through this study, I present evidence that this is very much the case in English, but not in Spanish.

\section{THE STUDY}

The specific purpose of this study ${ }^{3}$ was to elicit reactions to naturalistic, social media-based usages of SC from native speakers of English and Spanish. The study was situated in an interface designed to resemble Facebook, which served to present the tokens of SC and DC in an environment where participants had likely encountered them before. Consequently, this platform allowed the participants to be as comfortable as possible, as social media is likely something they are familiar and at ease with to a greater extent than a standard experiment format.

3 This experiment is one part of a three-study dissertation on the Said Construction, completed in 2020. It is situated within larger corpus-based analyses of SC/DC in both English and Spanish. 


\subsection{PARTICIPANTS: ENGLISH STUDY}

204 participants were recruited using prolific.ac, which has many available selection criteria for narrowing down an eligible participant pool. This study was made available to participants who were over 18 years of age and were born in and currently living in the United States. Table 1 below shows the distribution of participant ages for this study:

\begin{tabular}{|l|l|}
\hline Number of participants & Age range \\
\hline 52 & $18-25$ \\
\hline 91 & $26-35$ \\
\hline 33 & $36-45$ \\
\hline 28 & $46+$ \\
\hline
\end{tabular}

Table 1. Participant Ages, English study.

Participants also had to report having spent the majority of their life and time in the U.S. While participants were not required to be monolingual English speakers, they were required to report English as their primary language and the language in which they conduct the majority of their day to day life. Out of Prolific's 40,000+ participant pool, 13,528 were eligible for the study. Participants took an average of only 5 minutes to complete the study, and were paid $\$ 1.05$ (or $\$ 12.60 /$ hour).

\subsection{METHODS}

\subsubsection{ENGLISH STUDY}

The study consisted of two experimental blocks each containing ten sentences. Half of the sentences were SC-containing sentences and the other half contained standard determiners. The sentences in the experiment blocks were identical, varying only by use of said or a standard determiner such as that or the. The sentences were presented visually in a way that closely resembled Facebook; sentences were accompanied by a "profile picture" and a name of the assumed speaker/poster of the status. Social media profile photos were obtained either via either free stock photography or from friends and colleagues with permission from the individuals present in the photos, as approved by the IRB. These photos were cropped and sized down to a standard Facebook thumbnail size, approximately one square inch. Photos were chosen that contained individuals that matched the potential speaker of the sentences based on the information presented in the sentences. For example, two sentences in the study mentioned a baby; one was accompanied by a profile picture containing a family with a pregnant mother, and the other by a photo of a dog standing next to a newborn. An example of an item of stimuli is shown in figure 1 . 


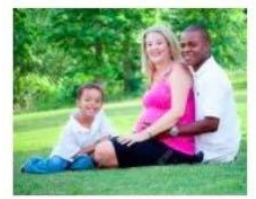

Jamie W.

A $10 \mathrm{lb}$ baby doesn't sound heavy...unless said baby isn't content \& won't nap unless you are holding them \& standing up.

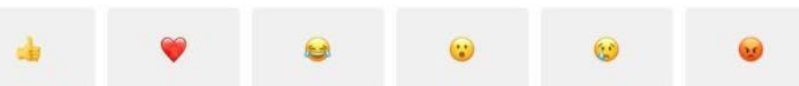

Figure 1. Sample of study stimuli; photography licensed through stock site. See Appendix A for complete stimuli. ${ }^{45}$

Participants were instructed to read each sentence and react to it as if they were on a social media site. Response data was analyzed for relationships between the determiner the sentence contained and the reaction emoji the participant used. I hypothesized that SCcontaining sentences would be more likely to use a emoji when compared with the duplicate sentence using a standard determiner, which I predicted would be more likely to use a standard reaction response, $\frac{2}{3}$. This is rooted in the idea that the unexpectedness of once-formal saidin an informal context could be interpreted as humorous in the discourse ${ }^{6}$. An overview of the meaning of each of the Facebook reaction emoji is available below, in Table $2^{7}$.

\begin{tabular}{|l|l|c|}
\hline Use & Title & Emoji \\
\hline $\begin{array}{l}\text { The original, sole reaction available on Facebook until the introduction of the } \\
\text { rest of the reaction options in early 2016. This reaction denotes general } \\
\text { acknowledgement and support. }\end{array}$ & & \\
\hline $\begin{array}{l}\text { A stronger reaction than the generic "thumbs up" and is used for expressing } \\
\text { more enthusiasm or support than could be conveyed by a thumbs up. }\end{array}$ & "Love" & \\
\hline $\begin{array}{l}\text { Reserved for posts that readers interpret as humorous. It is the only reaction } \\
\text { that clearly expresses laughter and amusement. }\end{array}$ & "Heehee" & \\
\hline $\begin{array}{l}\text { Used for surprising posts and to express shock. This seems to be used when a } \\
\text { "like" doesn't seem quite right but users still want to react. }\end{array}$ & "Wow" & $\because$ \\
\hline $\begin{array}{l}\text { Often used to show disapproval over wrongful actions. This is often seen in } \\
\text { response to controversial, political or news oriented posts. }\end{array}$ & "Angry" \\
\hline $\begin{array}{l}\text { Used to show empathy over a sad post, or similarly to the angry emoji in } \\
\text { reaction to upsetting or controversial stories. }\end{array}$ & "Sad" \\
\hline
\end{tabular}

Table 2. Meanings of Facebook reaction emoji. Descriptions based in explanations provided in Moreau 2018 and Constine 2016.

\footnotetext{
4 This block 1 token contains the NP said baby. An identical sentence in block 2 contained that baby.

5 Photo licensed through 123RF.com

6 Violations of Expectations principle, Acton 2014

7 It is worth noting that at the time of this study, Facebook had not yet added the "care" emoji, which is depicted as a sympathetic yellow emoji face hugging a heart. This was added after the onset of COVID-19, and is still currently unavailable in Unicode.
} 


\subsubsection{SPANISH STUDY}

An identical study was conducted with native Spanish speakers on the similar use of "dicho" (the dicho construction, or DC). Stimuli was translated by a native Spanish speaker from Mexico who was trained as a court translator and understands the importance of maintaining the intended meaning of a discourse within a translation. Where necessary, she helped adjust stimuli to be more relevant to a Spanish speaking participant base. For instance, there was an item in the English study that talked about sweet potatoes:

"So... in theory I like sweet potatoes, but said theory includes loads of brown sugar, butter, and marshmallows."

The translator expressed concern that this sentence would not directly translate in a way that would be relevant to Spanish speaking participants, as sweet potatoes are not part of the standard Mexican diet. Instead, she developed a similar sentence using plantano macho, which is a dish consisting of plantains that are fried and eaten with sugar and cream:

"En teoría me encanta el plántano macho, pero dicha teoría incluye que se fían, mucha azúcar y crema."

[In theory I like plántano macho, but said theory includes lots of sugar and cream.]

The study was designed, recruited and implemented identically to the English study. A complete list of stimuli from this study is available in Appendix B.

\section{RESULTS}

\subsection{ENGLISH STUDY RESULTS}

For task 1, the breakdown of total emoji responses for SC-containing sentences and standard determiner-containing sentences are shown in Table 3.

\begin{tabular}{|l|l|l|}
\hline Standard D-containing Sentences & SC-containing Sentences & Emoji \\
\hline $35 \%$ & $34 \%$ & \\
\hline $14 \%$ & $13 \%$ & \\
\hline $25 \%$ & $30 \%$ & $\ddots$ \\
\hline $15 \%$ & $13 \%$ & $\ddots$ \\
\hline $5 \%$ & $5 \%$ & 6 \\
\hline $5 \%$ & $4 \%$ & $\%$ \\
\hline
\end{tabular}

Table 3. Reaction emoji with determiner type. 
From this unanalyzed data, we see that almost all emoji categories are the same (within 1-2 percentage points) between determiner groups. The laughter/haha emoji is the only emoji that differs by a larger range, showing that participants are more likely to react to sentences containing $\mathrm{SC}$ with a humorous response than sentences that contain a standard determiner.

This data was analyzed using a general linear model, specifically focusing on the relationship between determiner type and emoji usage. In this model, the goal was to see if a $\Theta$ reaction could be predicted by the type of determiner used in the sentence, by looking for a correlation between an SC-containing sentence and the use of a emoji as opposed to this same emoji with a standard determiner-containing sentence. This model was run controlling for participant, and with and without controlling for the specific question participants were answering. The effect was significant in both models, but slightly more significant when including the question as a random intercept. In this analysis, values such that $\mathrm{p}<.05$ are significant.

As shown in table 4, there was a significant effect between determiner and reaction emoji used. These results show that sentences containing SC were significantly more likely to be rated with a $\Theta$ reaction than sentences containing a standard determiner, with a value of $[p<.001]$.

\begin{tabular}{|l|l|l|l|l|}
\hline $\operatorname{pr}(>|z|)$ & z value & Std. Error & Estimate & \\
\hline .00032 & -3.598 & .2904 & -1.0450 & intercept \\
\hline .00450 & -2.841 & .1088 & -.3092 & Standard determiner \\
\hline
\end{tabular}

Table 4. Fixed effects for social meaning experiment task 1.

\begin{tabular}{|l|l|l|}
\hline Std. Dev. & Variance & Group \\
\hline .6168 & .3804 & Participant (intercept) \\
\hline .8728 & .7619 & Question (intercept) \\
\hline
\end{tabular}

Table 5. Variance and standard deviation for random intercepts.

\subsection{SPANISH STUDY RESULTS}

Unlike in English, the Spanish study showed no significant relationship between the use of dicho and the $Q$ reaction. Table 6 demonstrates this, with the haha emoji as the intercept. Furthermore, there was no significant effect between any individual participant or question and the likelihood of a $\Leftrightarrow$ reaction (table 7).

\begin{tabular}{|l|l|l|l|l|}
\hline $\operatorname{pr}(>|z|)$ & z value & Std. Error & Estimate & \\
\hline .000126 & -3.834 & .30024 & -1.15122 & intercept \\
\hline .789281 & -0.267 & .10903 & -.02914 & Determiner type \\
\hline
\end{tabular}

Table 6. Fixed effects for Spanish study.

\begin{tabular}{|l|l|l|}
\hline Std. Dev. & Variance & Group \\
\hline .2919 & .08521 & Participant (intercept) \\
\hline .9116 & .83099 & Question (intercept) \\
\hline
\end{tabular}

Table 7. Variance and standard deviation for Spanish study. 


\section{DISCUSSION}

The main purpose for creating an experimental methodology centered around social media was to make this study as naturalistic as possible both in terms of how the stimuli were presented, and in how the participants interacted with it. SC can be readily observed in social media, and with Americans spending an estimated 40 or more minutes per day on Facebook, it is highly likely that participants encounter SC during their normal social media usage (FRIER 2014). With this in mind, I created an experimental interface that allowed participants to complete a task that most likely looks like something they already spend a lot of time doing on their own.

I hypothesized that if SC does convey a humorous social meaning, sentences containing it should be reacted to differently than sentences containing a standard determiner. This was reflected in the data from the English study, which showed that SC-containing sentences were significantly more likely to receive a humorous reaction than standard determiner-containing sentences, which were more likely to receive a standard "like/ $\mathrm{h}$ " or "love/ $\bullet$ " reaction. While there was a significant effect between determiner type and emoji reaction, there was surprisingly not a significant effect between the age of the participant and the use of the reaction. This could likely be due to the distribution of the ages of participants; $75 \%$ of participants were under the age of 35 . Further studies with more balanced age groups would be needed to account for a potential age effect. These patterns did not hold in the Spanish study, suggesting that the use of dicho is not interpreted as humorous among Spanish speakers, and that the language may have maintained this construction as a more formal one. Although SC and DC are distributionally similar in the two languages, they are used and interpreted differently by their speakers.

A potential improvement to this methodology would be to recruit an even number of participants across age-groups. As noted in Table 1, participants were broken down into the following categories: $18-25,26-35,36-45$, and $46+$. While prolific.ac allows the research to specify a minimum and maximum age for participants, it does not allow for further subdivision among specific age groups. The majority of participants for this study were in the youngest two age groups, and no age effect was observed. I would hypothesize that, with a balanced age sample, we would see a significant effect across age groups, with the younger groups more likely to use a "haha/@" reaction. With its roots in formal language, it follows that older participants would consider SC a more formal construction and would be less likely to interpret it as having a humorous social meaning.

This experiment allowed participants to interact with SC in the way they are most likely to encounter it, eliciting data that gives us a picture of how it is used and interpreted in this moment in time. This picture may not have been accurate 20 years ago, and perhaps will not be so 20 years in the future, but it serves as a starting point for future research, 
potentially branching into other forms of online discourse. Furthermore, this social mediacentered methodology could easily be adapted to investigate other types of linguistic phenomena, especially those asking social meaning-related questions about how language is interpreted in this now common form of discourse. Social media has become an invaluable tool for observing language patterns and seeing change happen; it is only natural that sociolinguistic experimentation methods should adapt to make use of this resource. While this experiment was modeled after Facebook and used Facebook's default reactions bar, it would not be far-fetched to create a novel social media type experiment platform with reactions specifically tailored for answering specific questions. Since many people spend multiple hours per week on social media, these types of experiments are easy for participants to use and understand, and can provide compelling data for questions that can be answered without acoustic data. Facebook as a platform is limited in terms of what we can examine linguistically, but using it as a starting point and model from which to base experimental methodologies could lead to exciting linguistic research.

\section{ACKNOWLEDGEMENTS}

Funding for this project was made possible by a Rackham Graduate Student Research Grant from the University of Michigan.

Appendix A:

Social Meaning experiment stimuli, English

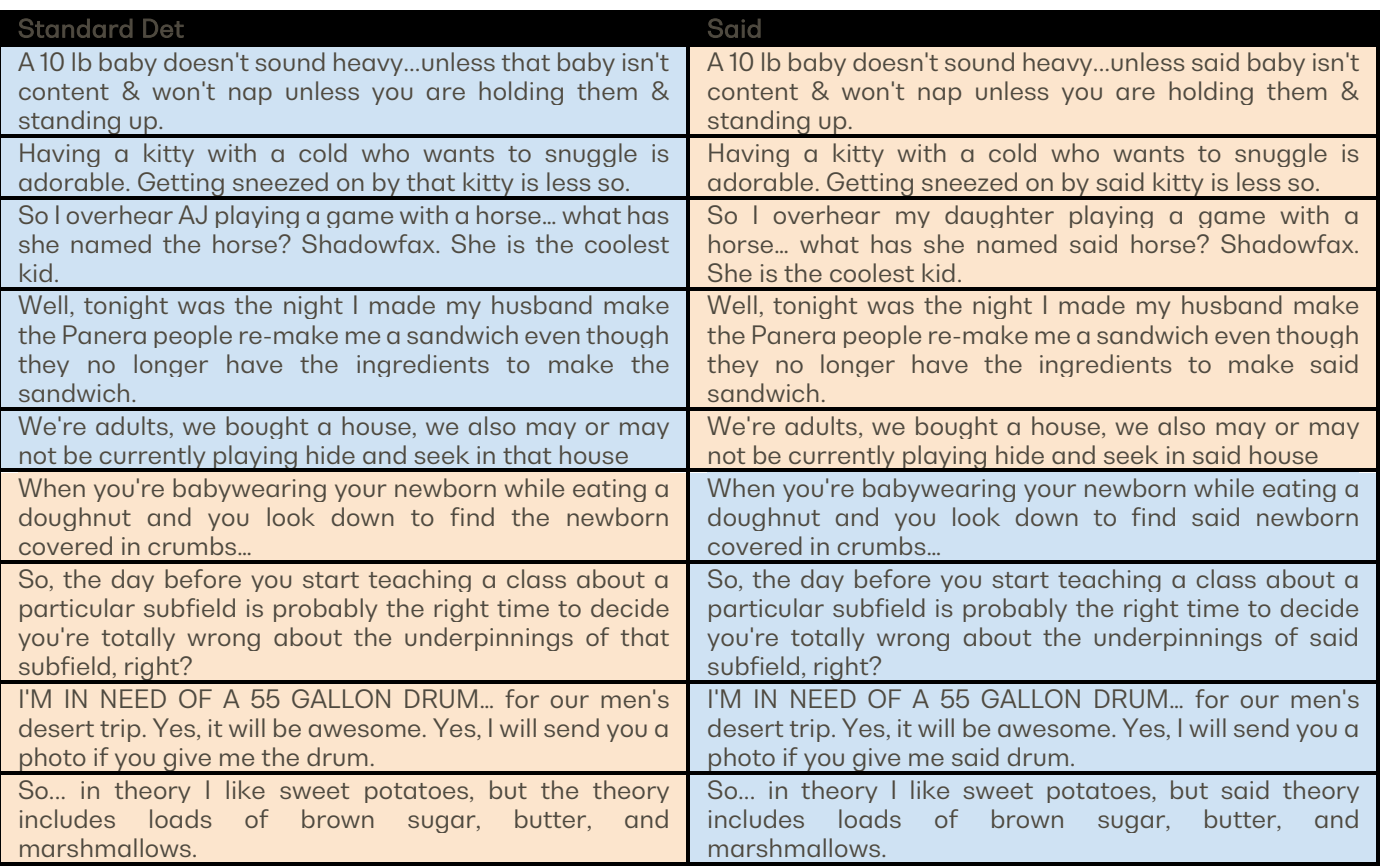


Hypothetically, if someone really misses playing a real piano, who do I know that has one in their home and wouldn't mind letting that person come by to play it every once in a while? Asking for a friend.
Hypothetically, if someone really misses playing a real piano, who do I know that has one in their home and wouldn't mind letting said person come by to play it every once in a while? Asking for a friend.

Appendix B

Social meaning experiment stimuli, Spanish

\begin{tabular}{|c|c|}
\hline Standard Det & cho \\
\hline $\begin{array}{l}\text { Un bebé de } 5 \text { kilos no suena pesado... a menos que ese } \\
\text { bebé no esté contento y no tome siesta y que lo estés } \\
\text { cargando mientras estás parado. }\end{array}$ & $\begin{array}{l}\text { Un bebé de } 5 \text { kilos no suena pesado... a menos que } \\
\text { dicho bebé no esté contento y no tome siesta y que lo } \\
\text { estés cargando mientras estás parado. }\end{array}$ \\
\hline $\begin{array}{l}\text { Tener un gatito con resfriado que quiere acurrucarse es } \\
\text { adorable. Que te estornude ese gatito no lo es. }\end{array}$ & $\begin{array}{l}\text { Tener un gatito con resfriado que quiere acurrucarse es } \\
\text { adorable. Que te estornude dicho gatito no lo es. }\end{array}$ \\
\hline $\begin{array}{l}\text { Así que escuche a mi hija jugar un juego que tiene que } \\
\text { ver con un caballo...¿como le ha llamado a ese caballo? } \\
\text { Galante. Ella es una niña genial. }\end{array}$ & $\begin{array}{l}\text { Así que escuche a mi hija jugar un juego que tiene que } \\
\text { ver con un caballo...¿como le ha llamado a dicho } \\
\text { caballo? Galante. Ella es una niña genial. }\end{array}$ \\
\hline $\begin{array}{l}\text { Bueno, hoy fue la noche en la que hice que mi esposo } \\
\text { hiciera que gente del restaurante volviera a hacerme mi } \\
\text { sándwich a pesar de no tener los ingredientes para } \\
\text { hacer ese sándwich. }\end{array}$ & $\begin{array}{l}\text { Bueno, hoy fue la noche en la que hice que mi esposo } \\
\text { hiciera que gente del restaurante volviera a hacerme } \\
\text { mi sándwich a pesar de no tener los ingredientes para } \\
\text { hacer dicho sándwich. }\end{array}$ \\
\hline $\begin{array}{l}\text { Somos adultos, compramos una casa y pudiera ser o no } \\
\text { que ahora mismo estemos jugando a las escondidillas } \\
\text { en esa casa. }\end{array}$ & $\begin{array}{l}\text { Somos adultos, compramos una casa y pudiera ser o no } \\
\text { que ahora mismo estemos jugando a las escondidillas } \\
\text { en dicha casa. }\end{array}$ \\
\hline $\begin{array}{l}\text { Cuando cargas a tu recién nacido mientras comes una } \\
\text { dona y miras hacia bajo para encontrar a ese recién } \\
\text { nacido cubierto en migajas de pan. }\end{array}$ & $\begin{array}{l}\text { Cuando cargas a tu recién nacido } \\
\text { dona y miras hacia bajo para enco } \\
\text { nacido cubierto en migajas de pan. }\end{array}$ \\
\hline $\begin{array}{l}\text { Así que el día antes de comenzar a enseñar una clase } \\
\text { acerca de un tema es probablemente el mejor } \\
\text { momento de decidir si estás totalmente mal acerca de } \\
\text { los fundamentos de ese tema. }\end{array}$ & $\begin{array}{l}\text { Así que el día antes de comenzar a enseñar una clase } \\
\text { acerca de un tema es probablemente el mejor } \\
\text { momento de decidir si estás totalmente mal acerca de } \\
\text { los fundamentos de dicho tema. }\end{array}$ \\
\hline $\begin{array}{l}\text { Necesito un barril de } 200 \text { litros... para nuestro viaje de } \\
\text { hombres al desierto. Si, va a ser increíble. Si, te } \\
\text { mandaré una foto si me das ese barril. }\end{array}$ & $\begin{array}{l}\text { Necesito un barril de } 200 \text { litros... para nuestro viaje de } \\
\text { hombres al desierto. Si, va a ser increíble. Si, te } \\
\text { mandaré una foto si me das dicho barril. }\end{array}$ \\
\hline $\begin{array}{l}\text { En teoría me encanta el plátano macho, pero esa teoría } \\
\text { include que se fían, mucha azúcar y crema. }\end{array}$ & $\begin{array}{l}\text { En teoría me encanta el plátano macho, pero dicha } \\
\text { teoría include que se fían, mucha azúcar y crema. }\end{array}$ \\
\hline $\begin{array}{l}\text { Hipotéticamente, si alguien extraña tocar un piano de } \\
\text { verdad, a quien conozco que tenga uno en su casa y a } \\
\text { quien no le importaría dejar a esa persona ir a tocarlo } \\
\text { de vez en cuando? Preguntando por una amiga. }\end{array}$ & $\begin{array}{l}\text { Hipotéticamente, si alguien extraña tocar un piano de } \\
\text { verdad, a quien conozco que tenga uno en su casa y a } \\
\text { quien no le importaría dejar a dicha persona ir a tocarlo } \\
\text { de vez en cuando? Preguntando por una amiga. }\end{array}$ \\
\hline
\end{tabular}

\section{REFERENCES}

ACTON, ERIC. (2014). Pragmatics and the social meaning of determiners. Doctoral dissertation, Stanford University.

CAMPBELL-KIBLER, KATHERINE. (2009). The nature of sociolinguistic perception. Language Variation and Change,21(1), 135-156. doi:10.1017/S0954394509000052

CONSTINE, JOSH. (2016). Facebook Enhances Everyone's Like With Love, Haha, Wow, Sad, and Angry Buttons. Techcrunch.com

FRIER, SARAH. 2014. Facebook's Second-Quarter Revenue, Profit Tops Estimates. Bloomberg.

<https://www.bloomberg.com/news/articles/2014-07-23/Facebook-posts-second-quarter-revenue-profit-toppingestimates>

MOREAU, ELISE. (2018). How to use Facebook Reactions. Lifewire.com: https://www.lifewire.com/how-to-useFacebook-reactions-3894307

STEVERS, ALICIA D. (2020). The said construction: Usage, change and social meaning in English and Spanish. Doctoral Dissertation, University of Michigan 